\title{
PENGALAMAN SPIRITUAL PEREMPUAN DENGAN KANKER SERVIKS
}

\author{
Dwi Dahlia Susanti ${ }^{12^{*}}$, Achir Yani S. Hamid ${ }^{3}$, Yati Afiyanti ${ }^{3}$ \\ 1. Poltekkes Kemenkes Tasikmalaya Program Studi Keperawatan, Tasikmalaya 46115, Indonesia \\ 2. Program Studi Magister Fakultas Ilmu Keperawatan Universitas Indonesia, Depok 16424, Indonesia \\ 3. Fakultas Ilmu Keperawatan Universitas Indonesia, Depok 16424, Indonesia \\ *Email:dwi.dahlia@yahoo.com
}

\begin{abstract}
Abstrak
Studi kualitatif fenomenologi ini dilakukan untuk memperoleh pemahaman yang mendalam tentang pengalaman spiritual perempuan dengan kanker serviks dalam konteks asuhan keperawatan kanker serviks dan bagaimana perempuan dengan kanker serviks memaknai pengalaman tersebut. Partisipan dipilih dengan metode purposif sebanyak enam perempuan dengan kanker serviks yang dirawat di sebuah RS di Jakarta. Data diperoleh dengan melalui wawancara mendalam dan dilengkapi catatan lapangan. Analisis data dengan teknik Colaizzi menghasilkan sepuluh tema. Hasil penelitian ini mengungkapkan kehidupan perempuan dengan kanker serviks diawali dengan ketidakpastian dan mengalami penderitaan sepanjang hidupnya tetapi semangat, keyakinan akan Tuhan, dan harapan menjadikan kehidupannya lebih pasti. Hasil penelitian ini memberikan implikasi terhadap pelayanan keperawatan untuk meningkatkan pelaksanaan asuhan keperawatan yang holistik terhadap klien dengan kanker serviks.
\end{abstract}

Kata kunci: kanker serviks, pengalaman spiritual

\begin{abstract}
This phenomenological qualitative study was used to examine a comprehensive understanding on the women's spiritual experience and the way they perceive it in the context of cervical cancer nursing care. Participants were selected using purposive method. Six women with cervical cancer hospitalized at a hospital in Jakarta were participated in the research. Data were collected through in-depth interviews serial and field notes. Data were analyzed by Colaizzi's technique. The research revealed ten themes. Women with cervical cancer had spiritual experiences as they felt uncertainties and suffered in their whole life. However, the motivation, the belief in God brought their hopes and made their lives brighter. The result of this research recommends that the holistic nursing process implementation to cervical cancer clients should be improved.
\end{abstract}

Keywords: cervical cancer, spiritual experience

\section{Pendahuluan}

Kanker serviks merupakan salah satu kanker yang banyak dialami oleh perempuan di seluruh dunia. Yayasan Kanker Indonesia (2009) memperkirakan bahwa setiap hari terdapat 20 sampai 25 perempuan yang meninggal akibat kanker serviks dan diperkirakan 52 juta perempuan Indonesia berisiko terkena kanker serviks.

Rendahnya kesadaran untuk melakukan pemeriksaan dini kanker serviks me-nyebabkan kanker ini menjadi pembunuh perempuan nomor satu di Indonesia. Perempuan yang didiagnosis kanker serviks dan yang sedang menjalani penanganannya dapat me- ngalami peningkatan masalah depresi, cemas, marah, dan bingung (Bradley, et al., 2006).

Kanker serviks berhubungan dengan perubahan pada organ reproduksi perempuan yang dianggap sebagai bagian yang sangat penting bagi perempuan. Kematian, dampak yang serius terhadap kehidupan, serta kehilangan kemampuan melakukan hubungan seksual merupakan ketakutan yang dirasakan oleh perempuan yang mengalami kanker serviks (Villafuerte, et al., 2007).

Dampak utama kanker serviks adalah penurunan kualitas hidup perempuan yang mengalami penyakit kanker serviks (Herzog \& Wright, 2007). 
Penurunan kualitas hidup dapat menyebabkan penderitaan. Penderitaan yang dialami oleh individu yang mengalami kanker pada fase terminal memiliki 3 (tiga) komponen, antara lain; kehilangan otonomi, berkurangnya harga diri, dan hilangnya harapan yang menunjukkan sudah tidak adanya makna hidup bagi individu dengan kanker (Morita, et al, 1999).

Kompleksnya masalah yang dialami oleh individu yang mengalami kanker menyebabkan munculnya kebutuhan spiritual. Penelitian Halstead dan Hull (2001, dalam Mauk \& Schmidt, 2004) mengenai pengalaman spiritual pada 10 orang perempuan dengan limfoma non-Hodgkin, kanker payudara, dan kanker ovarium diketahui tiga tema antara lain; (1) makna kanker bagi dirinya, (2) menyadari adanya keterbatasan, serta (3) belajar hidup dalam ketidakpastian.

Penelitian ini bertujuan untuk mendapatkan pemahaman yang mendalam mengenai pengalaman spiritual perempuan dengan kanker serviks dan bagaimana perempuan dengan kanker serviks memaknai pengalaman tersebut.

\section{Metode}

Penelitian ini menggunakan metode kualitatif dengan pendekatan fenomenologi untuk menggali pengalaman spiritual perempuan dengan kanker serviks. Dengan metode ini dapat diperoleh data yang lengkap, mendalam, kredibel, dan bermakna.

Data diperoleh dengan wawancara mendalam yang dilengkapi dengan catatan lapangan dan pedoman wawancara semi berstruktur. Data yang diperoleh dibuat transkrip data.

Analisis data dilakukan dengan menggunakan teknik Collaizi yang dikutip dari Speziale dan Carpenter (2003). Transkrip data dibaca berulang dan kata kunci telah diidentifikasi, selanjutnya data tersebut dibuat kategori. Peneliti selanjutnya menentukan sub-sub tema dan tema potensial. Tema tersebut divalidasikan kepada partisipan kemudian ditentukan tema akhir.

\section{Hasil}

\section{Karakteristik Partisipan}

Sebanyak enam orang partisipan berpartisipasi dalam penelitian ini. Usia partisipan antara 42 tahun sampai 64 tahun. Tingkat pendidikan bervariasi dari SD, SMP, dan SMA. Empat orang partisipan tidak bekerja, satu partisipan bekerja sebagai PNS dan satu orang bekerja sebagai pedagang makanan.

Seluruh partisipan beragama Islam. Lima dari enam partisipan masih terikat perkawinan sedangkan satu partisipan adalah janda. Hampir seluruh partisipan memiliki anak antara satu sampai enam hanya satu partisipan yang tidak memiliki anak. Tiga partisipan berasal dari suku Jawa, lainnya berasal dari suku Sunda, Betawi, dan Minang.

Waktu diagnosis mulai 3 (tiga) hari sampai 2 (dua) tahun. Partisipan dirawat di sebuah rumah sakit di Jakarta untuk dilakukan perbaikan kondisi umum, persiapan nefrostomi, menjalani kemoterapi, dan radiasi.

\section{Tujuan Hidup Perempuan dengan Kanker Serviks}

Makna hidup seseorang akan tampak dari tujuan hidup yang dijadikan semangat untuk bertahan dalam penderitaannya. Pada penelitian ini diketahui bahwa alasan perempuan dengan kanker serviks tetap bertahan dengan penderitaannya adalah tanggung jawab, membalas budi kebaikan suami, serta menjaga hubungan sosial dengan orang lain.

Ketiga alasan tersebut menjadikan perempuan harus tetap kuat untuk menjalani kehidupan dengan kanker serviks dan menghadapi segala permasalahan yang dialaminya akibat kanker serviks.

"Saya kan udah lima bulan dirawat disini anakanak saya kan ditinggal di Lampung jadi selama ini saya tidak pernah ketemu mereka makanya saya pokoknya mau rajin kemo mau rajin disinar biar cepet sembuh biar urusan disini selesai, soalnya saya kan harus ngurus anak-anak saya kasihan mereka udah lama saya tinggalkan..." (P5). 
"Saya suka kasian melihat suami saya sepertinya dia cape sekali mengurus segala keperluan saya sampai dia harus meninggalkan pekerjaannya (sambil menangis) makanya kalo nanti saya sudah sembuh saya mau mengurus suami saya ingin membalas budi..." (P4).

"Saya pengen kumpul lagi dengan teman-teman di pengajian kan enak tuh sekalian saya bisa beramal." (P3).

\section{Nilai Kanker Serviks bagi Penderitanya}

Setiap manusia akan memberikan nilai yang berbeda terhadap suatu peristiwa. Kanker serviks dinilai oleh penderitanya sebagai ujian, hukuman, penghapus dosa, teguran, dan nikmat.

"Saya menganggap ini sebagai ujian di saat $m$ saya lagi enak-enaknya beribadah karena kan saya sudah menopause tuh...tiba-tiba geletek saya jadi begini." (P3).

"Kayaknya kalo sakit itu kan bisa mengurangi dosa-dosa kita yang udah-udah mudah-mudahan deh dengan sakit ini kita diampuni dosa-dosa yang lalu... namanya manusia kan punya banyak dosa apa aja seumur hidup..” (P2).

"Mungkin saya begini adalah hukuman atas dosa-dosa yang telah saya lakukan dulu, ya dosa apa aja." (P5).

"Sakit ini mungkin teguran buat saya, saya kan dulu kalo sholat sering lupa-lupa, saya capenya nyari duit makanya Alloh ngasih penyakit ini biar sayanya sadar.” (P1).

"Saya bersyukur saya sudah diberikan nikmat sehat selama 47 tahun dan pada saat ini saya sedang diberikan nikmat sakit ..." (P4).

\section{Stigma Masyarakat Mengenai Kanker Serviks}

Kanker serviks merupakan penyakit yang memiliki stigma negatif dalam masyarakat. Masyarakat menilai bahwa penyakit kanker adalah penyakit yang mematikan dan berbahaya.

"Orang-orang bilang penyakit ini susah diobati, ganas, dan bikin cepet mati kalo udah begitu saya jadi suka putus asa." (P2).
"Kata orang sakit beginian sakit yang membahayakan, serem ... jadi ngecilin hati.” (P3).

\section{Respon Emosional Penderita Kanker Serviks}

Seluruh partisipan dalam penelitian ini mengalami reaksi emosional dengan diagnosis yang disampaikan. Reaksi ini merupakan bentuk respon terhadap kehilangan yang dialami partisipan.

"Awalnya saya tidak terima kenapa saya yang harus mengalami?” (P4).

"Saya tuh kepikir begini ya.. saya sembahyang sering dan ga pernah melakukan hal yang engga-engga kok saya dikasih penyakit seperti ini..." (P5).

"Saya sama sekali tidak kaget... saya cuma berpikir oh ini toh penyakit kanker yang orangorang bilang, sudah gitu aja." (P6).

Penderitaan terus menerus yang dirasakan oleh seseorang mengarahkannya pada satu proses pencarian kekuatan di luar dari kekuatan dirinya. Tuhan sering dianggap sebagai pemberi kekuatan tertinggi bagi kehidupan, tetapi partisipan yang baru saja didiagnosis kanker serviks menyatakan bingung. Berikut penyataan partisipan:

"Penyakit ini kan datangnya dari Alloh ya kita cuma bisa pasrah aja." (P2).

"Kita kan menerima kalo orang Jawa bilang nerimo, itu kita ikhlas kalau ada apa-apa kalo kita ga ikhlas itu kalo kitanya takut....”(P6).

"Saya itu bingung... saya ga tahu persis penyakit saya ini sebenernya seperti apa terus nantinya saya gimana... mungkin ngasih taunya sama anak saya tapi saya tidak diberitahu ..." (P1).

\section{Gangguan Peran Perempuan dengan Kanker Serviks}

Penderitaan yang dialami oleh perempuan dengan kanker serviks menyebabkan mereka tidak mampu menjalankan perannya dalam rumah tangga. Peran sebagai ibu, istri, dan pengurus rumah tangga tidak dapat dilakukan secara maksimal. 
"Ya itu... sekarang bapaknya yang mengerjakan semuanya di rumah ngepel, nyapu, cuci,, saya sih ngga saya kan badannya gak enak jadi perlu istirahat.. saya suka kasian saya suami saya tapi mau gimana lagi... anak-anak juga jadi ga saya urus yang ngurus sekarang neneknya karena kan saya musti berobat di Jakarta. Ini anak-anak saya kan di Lampung sana..."(P5).

“.... Selama sakit saya selama 2 (dua) tahun saya sudah tidak pernah hubungan lagi sebenarnya kan kalo udah selesai pengobatan katanya boleh tapi saya enggak. saya udah coba tawarin ke bapaknya tapi dia gak mau, mungkin karena kasihan ya sama saya.. saya juga dah suruh dia kawin lagi tapi gak mau juga..."(P6).

\section{Dukungan Sosial yang Diperoleh Perempuan dengan Kanker Serviks}

Dukungan dari orang-orang sekitar penderita kanker serviks adalah hal yang sangat penting. Dukungan sosial yang didapatkan dapat meningkatkan semangat untuk terus bertahan. Dukungan emosional, finansial, spiritual, dan informasi dinyatakan partisipan sebagai pemberi semangat untuk menjalani kehidupan.

"Kalo udah ngumpul-ngumpul ama keluarga enak tuh.... Bapaknya ngasih dorongan, anak juga ngasih support jadi saya bersemangat lagi, adik saya juga suka ngebel nanyain keadaan saya dan ngasih dorongan buat saya..." (P3).

"Temen-temen kerja saya dulu di garmen tuh sus, mereka masih pada menyisihkan uang buat ngasih sumbangan buat saya... saya jadi terharu mereka begitu perhatian sama saya ..."(P4).

"Keluarga dan tetangga saya datang dan pada ngedoain." (P1).

\section{Menarik Diri dari Lingkungan}

Perubahan kondisi fisik yang diceritakan oleh beberapa partisipan menyebabkan mereka menarik diri dalam berhubungan dengan orang lain maupun sekitarnya. Kelemahan, keletihan, dan banyak- nya darah yang keluar menjadikan partisipan mengurangi hubungan dengan orang lain.

"Badan saya jadinya sering lemes karena sering banyak darah keluar... kan terus saya udah ga bisa kerja lagi.... saya memang ga bisa kan kalo keadaan begini jalan-jalan atau main-main untuk menemui mereka..." (P2).

"Kalo saya ketemu orang-orang malah saya suka gak enak denger omongan mereka yang macem-macem jadinya malah tambah ngecilin hati mendingan saya tinggal di rumah...." (P3).

"Keadaan saya kan begini suster... saya punya buntut istilahnya... kayak gini malah saya jadi gak enak hati... takut mereka pada cium bau saya yang tidak enak ini...." (P4).

\section{Kedekatan dengan Yang Maha Kuasa}

Partisipan merasa bahwa sering berdoa telah mendekatkannya dengan Alloh SWT. Partisipan sering berdoa agar dilancarkan segala urusan terutama dalam pengobatan disampaikan oleh partisipan. Meskipun demikian, partisipan mengaku bahwa frekuensi ibadahnya berkurang karena perubahan kondisi fisik.

"Saya merasa Alloh itu dekat... malah kalo saya meminta itu saya suka sampai nangis ... minta dibikin lancar urusan... eh iya, lancar berobat saya... jadi engga lama-lama, terus bayarannya juga jadi lebih ringan..." (P3).

"Biasa aja... sama aja ya berusaha untuk tetap mempertahankan sholat meskipun kadang-kadang bingung karena banyak darah keluar..." (P2).

\section{Harapan terhadap Kehidupan}

Harapan hidup merupakan salah satu domain spiritual dari pemahaman individu terhadap kehidupan. Oleh karena itu, harapan merupakan dasar dari aspek spiritual. Hampir semua partisipan mengungkapkan harapannya dengan mengatakan:

"saya ingin sembuh dan ingin sehat seperti semula". 


\section{Harapan terhadap Pelayanan Kesehatan}

Peran perawat sebagai pemberi asuhan keperawatan sangat menentukan kesehatan spiritual dari klien yang dirawatnya. Semua pertisipan mengatakan belum ada perawat yang secara khusus mengajaknya berbicara, menyentuh, dan mengeksplorasi pengalaman partisipan, atau secara khusus memberikan motivasi, untuk dapat menjalani hidup dengan kanker serviks. Namun, sikap perawat secara umum sudah dianggap baik.

"Paling ada petugas rohani datang ngasih ceramah sama ngasih doa itu ngingetin saya untuk tetap berdoa terus kan dibilangin kalo sakit ini adalah takdir Alloh Yang Maha Kuasa juga membuat saya semangat lagi..." (P4).

“... Ya sebenernye begini aja juga udah cukup perawatnya baek, tapi kalo lebih baek lagi bagus juga kan.. biar lebih perhatian ke pasiennya karena kan kita juga butuh diperhatikan... biar kite ga sedih terus biar kite semangat terus..."(P3).

\section{Pembahasan}

Respon awal seorang perempuan yang didiagnosis mengalami kanker serviks adalah mengingkari kenyataan bahwa dirinya mengalami penyakit kanker serviks. Kehidupan perempuan yang mengalami penyakit kanker serviks berada akan mengalami kondisi ketidakpastian (uncertainty) karena pengobatan yang dijalaninya memerlukan waktu, tenaga, dan materil yang tidak sedikit.

Pengobatan yang dijalaninya tersebut juga tidak sepenuhnya dapat memulihkan kondisi penderita pada keadaan semula. Sebaliknya, dampak dari pengobatan sendiri dapat menyebabkan masalah kesehatan lainnya. Hal ini menimbulkan stress yang terus menerus pada perempuan yang mengalami penyakit kanker serviks sehingga tidak hanya mempengaruhi penyesuaian fisik tapi juga penyesuaian psikologis (Lehman, et al., 1978 dalam Lubis \& Hasnida, 2009).

Berbagai kehilangan akibat penyakit kanker serviks dapat menyebabkan penderitaan (agony/ torment) bagi perempuan yang mengalaminya. Perubahan fisik dan psikologis yang terjadi akibat kanker serviks akan berpengaruh terhadap fungsi peran perempuan.

Berdasar hasil penelitian ini diketahui bahwa keluhan lemahnya fisik, pusing, dan seringnya darah yang dikeluarkan merupakan hambatan partisipan untuk melakukan peran yang selama ini dijalankannya. Peran sebagai ibu, istri, dan peran dalam mengurus rumah tangga harus diserahkan kepada orang lain.

Perempuan yang menderita kanker serviks menyerahkan semua peran yang selama ini dijalankannya kepada orang lain karena merasa tidak berdaya akibat penyakitnya (Kritcharoen, Suwan, \& Jirojwong, 2005). Masalah gangguan fungsi peran tersebut dirasakan sebagai masalah yang mengancam identitas perempuan seperti halnya kehilangan fungsi seksualitas (Otto, 2007).

Pada penelitian ini tidak terdapat konflik internal yang berhubungan dengan masalah aktifitas seksual karena partisipan telah melakukan komunikasi terbuka dengan pasangannya.

Beban psikologis pada perempuan dengan kanker serviks tidak hanya terjadi karena perubahan kondisi fisik yang dialaminya, tetapi juga karena adanya persepsi yang negatif dari masyarakat mengenai kanker. Stigma bahwa kanker serviks merupakan penyakit yang mematikan dan berbahaya menyebabkan perempuan dengan kanker serviks memilih menarik diri dari lingkungannya (Sellors, Muhombe, \& Castro, 2004).

Namun demikian, setiap penderita memaknai kanker serviks yang dideritanya secara beragam. Kanker serviks diyakini sebagai ujian, penghapus dosa, hukuman, teguran, bahkan dirasakan sebagai nikmat oleh penderita kanker. Craven dan Hirnle (2003) mengungkapkan bahwa seseorang yang merasakan suatu peristiwa yang menimpanya merupakan suatu ujian yang dilimpahkan kepadanya, maka akan meningkatkan kedalaman spiritual dan kemampuan kopingnya untuk memenuhi kebutuhan spiritualnya. 
Masyarakat di Indonesia umumnya menganggap bahwa penyakit kanker sebagai hukuman atas dosa yang telah dilakukan sekaligus cobaan dari Tuhan yang patut disyukuri (Hamid, 2008). Literatur lain menyatakan bahwa seseorang yang mampu mengidentifikasi kepercayaan spiritualnya secara positif akan menggunakan kepercayaan tersebut untuk menghadapi situasi kesehatannya secara positif pula sehingga akan menemukan arti dan tujuan hidupnya (Kozier, et al., 2004).

Studi yang dilakukan oleh Ashing, et al. (2003) dalam Lee, et al. (2007), menerangkan bahwa perempuan Asia yang menderita kanker payudara menunjukkan penyakit yang dideritanya adalah keinginan Tuhan dan Dia mempunyai kekuasaan untuk menentukan hasil akhir dari penyakit tersebut.

Keyakinan akan kekuasaan Tuhan tersebut menjadikan partisipan dalam penelitian ini, yaitu pasrah, ikhlas, dan menerima takdir yang diberikan oleh Tuhan. Respon berduka telah memasuki masa penerimaan jika individu telah menerima kondisi dan konsekuensi yang dialaminya (Ulrich, 2008).

Pada tahap ini penderita kanker telah mendapatkan kekuatan diri untuk berjuang melawan kanker yang dialaminya. Melalui kekuatan tersebut timbul harapan dalam menjalani kehidupan dengan penderitaan. Harapan merupakan salah satu domain spiritual dari pemahaman individu terhadap kehidupan sehingga harapan merupakan dasar dari aspek spiritual.

Penelitian ini menemukan bahwa harapan untuk sembuh merupakan harapan dari para partisipan. Harapan dapat membantu individu dalam menemukan arti dari sakit yang diderita yaitu ketika individu dengan kanker merasa tidak nyaman dengan gejala penyakit yang dirasakannya, meningkatnya ketidakmampuan dan takut menghadapi kematian (Fryback, 1993 dalam Potter \& Perry, 2005; O’Connor, 1990).

Harapan dapat membantu individu untuk menghadapi ketidaknyamanan, menjalani kehidupannya dengan penyakit yang diderita serta melangsung- kan kehidupan dengan penuh kekuatan. Harapan berhubungan erat dengan masalah spiritual (DePalo, 2009). Adanya hambatan dalam spiritual menyebabkan individu memiliki harapan yang rendah dan menyebabkan keputuasaan.

Berdoa merupakan terapi spiritual yang sering dilakukan oleh penderita kanker (Taylor, 2005). Dalam penelitian yang dilakukan oleh Wells, et al. (2000) mengungkapkan bahwa doa merupakan salah satu dari enam terapi komplementer yang dipilih oleh penderita kanker serviks. Greenwald dan McCorkle (2007) menyebutkan bahwa kepuasan akan dirasakan perempuan dengan kanker serviks ketika dirinya berdoa.

Harapan pada perempuan dengan kanker serviks juga dapat meningkat dengan adanya dukungan sosial. Perempuan dengan kanker serviks pada penelitian ini juga mendapatkan dukungan emosional, finansial, informasi, dan spiritual. Menurut Lin dan Bauer (2003), bahwa faktor penentu pencapaian kesejahteraan psikososial diantaranya adalah dukungan keluarga dan dukungan sosial.

Keluarga merupakan sistem sosial yang memiliki pengaruh besar terhadap kehidupan perempuan yang mengalami penyakit kanker serviks. Berdasarkan penelitian yang dilakukan Ginzburg, et al. (2008) mengenai dukungan sosial pada perempuan dengan kanker payudara diketahui bahwa kurangnya dukungan dari keluarga dapat menyebabkan stress pada perempuan yang mengalami kanker payudara.

Pengembangan harapan merupakan tanggung jawab perawat yang memberikan asuhan keperawatan (Gewe, 1994; Thompson, 1994 dalam Mauk \& Schmidt, 2004). McCloskey dan Bulechek (1999) (dalam Mauk \& Schmidt, 2004) menjelaskan bahwa perawat bertanggung jawab untuk melakukakan hope instillation, yaitu suatu cara untuk memfasilitasi pengembangan hasil positif dari suatu situasi.

Aktifitas tersebut ditujukan untuk membantu klien dalam menunjukkan bahwa proses penerimaan, menghadapi suatu situasi secara positif, percaya, 
meningkatkan hubungan klien dengan keluarga, memfasilitasi perawatan diri, menyediakan informasi yang akurat, memberikan pendidikan kesehatan, dan menyediakan lingkungan yang menunjang pada proses penyembuhan. Asuhan keperawatan yang holistik penting diberikan oleh perawat dalam melakukan asuhan keperawatan pada klien dengan kanker serviks.

\section{Kesimpulan}

Penelitian ini menunjukkan bahwa pengalaman spiritual perempuan dengan kanker serviks diawali sejak dirinya didiagnosis mengalami kanker serviks. Berbagai penderitaan dialami tidak hanya disebabkan oleh perubahan kondisi fisik dan psikologis, tetapi juga akibat perubahan sosial dan stigma masyarakat mengenai penyakit kanker serviks. Perempuan dengan kanker serviks mencoba mengembangkan harapan dalam ketidakpastian hidupnya. Harapan yang tumbuh seiring dengan doa yang mendekatkannya dengan Tuhan, dukungan sosial yang diterima serta tujuan hidup menjadikan dirinya dapat bertahan dalam menjalani kehidupannya dengan kanker serviks (WK, SW, TN).

\section{Referensi}

Bradley, S., Rose, S., Lutgendorf, S., Costanzo, E., \& Andeson, B. (2006). Quality of life and mental health incervical canceran endometrial survivor. Gynecologic Oncology, 100 (3), 479486.

Craven, R.F., \& Hirnle, C.J. (2003). Fundamental of nursing: Human health and function (4th Ed.). Washington: Lippincott Williams \& Wilkin.

DePalo, R. (2009). The role of hope and spirituality on the road ro recovery. The Exceptional Parent, 39 (2), 74-77.

Ginzburg, K., Wrensch, M., Rice, T., Farren, G., \& Spiegel, D. (2008). Breast cancer and psychosocial factors: Early stressfull life event, social support, and well being. Psychosomatic, 49 (5), 407 - 412. Doi: 10.1176/ appi.psy.49.5.407. (ISSN: 0033-3182).
Greenwald, H.P., \& McCorkle, R. (2007). Remedies life change among invasive cervical cancer survivor. Urology Nursing, 27 (1), 47-53. (PMID: 17390927).

Hamid, A.S. (2008). Bunga rampai: Asuhan keperawatan kesehatan jiwa. Jakarta: EGC.

Herzog, T.J., \& Wright, J.D. (2007). The impact of cervical cancer on quality of life: The component and means for management. Gynecologic Oncology, 107 (3), 572-577. Doi: 10.1016/ j.ygyno.2007.09.019.

Kozier, B., Erb, G., Berman., \& Snyder, S. (2004). Fundamental of nursing: Concept, process, and practise. Uper Saddle River: Perarson Education, Inc.

Kritcharoen, S., Suwan, K. \& Jirojwong, S. (2005). Persceptions gender roles, gender power relationships and sexuality in thai women following diagnosis and treatment for cervical cancer. Oncology Nursing Forum, 32 (3), 682-688. (PMID: 15897942)

Lee, E.E., Tripp-Reimer, T., Miller, A. M., Sadler, G., R., \& Lee, S. (2007). Korean american women's belief about breast and cervical cancer and association symbolic meaning. Oncology Nursing Forum, 34 (3), 713-720. Doi: 10.1188/ 07.ONF.713-720.

Lin, H.R., \& Bauer, W.S.M. (2003). Psychospiritual well-being in patients with advances cancer: An integrative review of the literature. Journal of Advanced Nursing, 44 (1), 69-80. (PMID: 12956671).

Lubis, N.L., \& Hasnida. (2009). Dukungan sosial pada pasien kanker, perlukah? Medan: USU Press.

Mauk, K.L., \& Schmidt, N.K. (2004). Spiritual care in nursing practise. Philadelphia: Lippincott Williams \& Wilkins.

Morita, T., Tsunoda, J., Inoue, S., \& Chihara, S. (1999). An exploratory analisys of existential suffering in Japanese terminally illness. Psycho-Oncology, 9 (2), 164-168. Doi: 10.1002/(SICI)1099-1611 (200003/04)9:2<164::AID-PON447>3.0.CO; 2-S. 
Otto, S.E. (2007). Oncology nursing (4th Ed.). St. Louis: Mosby, Inc.

Potter, P.A., \& Perry, A.G. (2005). Fundamental of nursing: Concept, process, and practice (4th Ed.). Philadelphia: Mosby.

Sellors, J., Muhombe, K., \& Castro, W. (2004). Palliative care for women with cervical cancer: A Kenya field manual. Seattle, WA: PATH Company.

Speziale, H.J.S., \& Carpenter, D.R. (2003). Qualitative research in nursing: Advancing the munanistic imperative (3rd Ed.). Philadephia: Lippincott Williams \& Wilkins.

Taylor, E. (2005). Spiritual complementary therapies in cancer care. Seminars in Oncology Nursing, 21 (3), 159-163. Doi: 10.1016/j.soncn.2005.04.003.
Ulrich, S. (2008). Cancer and grief. Diperoleh dari http://www.amazines.com/.

Villafuerte, B.E.P., Gomez, L.L.T., Betahncourt, A.M., \& Cervantes, M.L. (2007). Cervical cancer: A qualitative study on subjectivity, family, gender, and health services. Reproductive Health, 4 (2), 142-148. Doi:10.1186/1742-47554-2.

Wells, M., Sarna, L., Cooley, M.E., Brown., J.K., Chernecky, C., William, R.D., et al. (2007). Use of complementary and alternative therapies medicine to control systems in women living with lung cancer. Cancer Nurs, 30 (1), 45-55. (PMID: 17235219).

Yayasan Kanker Indonesia. (2009). 20-25\% perempuan meninggal akibat kanker serviks. Diperoleh dari http://www.depkominfo.gov/. 